\title{
Isolated hemihyperplasia
}

INSERM

\section{Source}

INSERM. (1999). Orphanet: an online rare disease and orphan drug data base. Isolated hemihyperplasia. ORPHA:2128

Isolated hemihyperplasia is a rare overg rowth syndrome characterized by an asymmetric regional body overgrowth, involving at least one limb, and associated with an increased risk of developing embryonal tumors, principally nephroblastoma (see this term) and hepoblastoma. 